\title{
Risiko Paparan Benzena Terhadap Kandungan Fenol Dalam Urin Pekerja Pengecatan Mobil Di Kecamatan Tampan Kota Pekanbaru Tahun 2017
}

\author{
Darnita Darwis ${ }^{1}$, Mubarak $^{2}$, Sofia Anita ${ }^{2}$ \\ ${ }^{1}$ Fasilitator Kesehatan Pamsimas Provinsi Riau \\ ${ }^{2}$ Dosen Program Studi Magister Ilmu Lingkungan Program Pascasarjana Universitas Riau \\ Jalan Pattimura No.09 Gedung I Gobah Pekanbaru, Telp. 0761-23742
}

\begin{abstract}
Benzene is well known as a good organic solvent for various processes in industry such as rubber industry, shoes, paint solvents and others. Benzene is a chemical that has long been known to be dangerous to human health because of carcinogenic. One of the informal sectors exposed to benzene is a car painting workshop. This study is intended to determine the levels of phenol in workers urine and analyze the effects of the exposureon the characteristics of the car painting worker in sub districts of Tampan Pekanbaru. The methods used in study are survey and interview. The analysis used in this research is a multiple linear regression, where the independent variable more than 2 variables. They are smoking habit, length of work, duration of exposure and use of PPE. The examination by using the UV-Vis spectrophotometer apparatus. The result showed that were 6 workers who had phenolythuramines level above $20 \mathrm{mg} / \mathrm{L}$ exceed of WHO standards. The analysis result found that is affect workers characteristic which is significant to the phenol level in workers urine that has exposed to the benzene.
\end{abstract}

Key words : Pekanbaru, benzene, car painting workshop, urinary phenol.

Benzena sudah dikenal sebagai pelarut organik yang baik untuk berbagai proses di industri seperti industri rubber, sepatu, pelarut cat, komponen dalam bahan bakar motor, komponen dalam detergent, pestisida dan pembuatan farmasi (Maywati, 2012). Benzena adalah karsinogenik pada manusia melalui paparan inhalasi (Rahim, et al, 2015). Benzena yang masuk dalam tubuh akan mengalami metabolisme yang utama menjadi benzena epoksida. Di dalam hati, benzena epoksida merupakan senyawa yang tidak stabil dan akan segera mengalami perubahan membentuk fenol yang akan dikeluarkan melalui urin. Oleh karena itu kandungan fenol digunakan sebagai indikator biologik atas paparan benzena pada tenaga kerja (Sugiharto, 2009).

Fenol dalam urin merupakan salah satu biomarker untuk pemaparan benzena. Standar WHO (2006) untuk kandungan fenol urin yang dianggap normal bila kurang dari $20 \mathrm{mg} / \mathrm{L}$ urin. Kandungan fenol dalam urin yang melebihi standar harus diwaspadai terhadap kejadian keracunan, karena merupakan gambaran tingkat pemaparan terhadap benzena. Semakin tinggi kandungan fenol dalam urin dapat diasumsikan semakin berat tingkat pemaparan benzena. Salah satu sektor informal yang sering terpapar dengan benzena yaitu bengkel cat mobil. Pekerja pengecatan mobil adalah salah satu bidang pekerjaan yang perlu mendapat perhatian karena jumlahnya yang terus berkembang, sementara itu risiko penyakit akibat kerjanya cukup besar.

Paparan benzena dalam kandungan tinggi menyebabkan efek narkotik dan iritasi pada mata dan saluran napas, paparan jangka panjang dengan kandungan rendah dapat berakibat supresi sumsum tulang dan dapat dihubungkan dengan kejadian leukimia atau gangguan sel darah lainnya. Populasi pekerja yang bekerja pada industri pengecatan mobil atau menggunakan benzena dapat terpapar dengan tingkat paparan tertinggi. Untuk itu perlu perhatian khusus pada pekerja demi keselamatan dan kesehatan kerja.

Proses pengecatan mobil menggunakan pelarut yang mengandung benzena sebagai bahan utama dalam proses bekerja yang dapat memberikan dampak merugikan terhadap kesehatan. Banyaknya pekerja yang tidak memakai alat pelindung diri saat bekerja, dan mengeluhkan rasa sesak, batuk dahak dan iritasi mata ketika melakukan pekerjaan mengecat ke bodi mobil serta banyaknya bengkel cat mobil 
yang berada di lingkungan perumahan, sehingga mengganggu warga dan lingkungan sekitar.

\section{BAHAN DAN METODE}

Penelitian ini telah dilakukan pada bulan Mei hingga Agustus 2017 di Kecamatan Tampan di Kota Pekanbaru (Gambar 1). Penelitian ini bertujuan untuk mengetahui kandungan fenol dalam urin dan menganalisis pengaruh karakteristik pekerja dengan paparan benzena. Metode penelitian menggunakan metode survei dan analisis deskriptif. Data primer dikumpulkan melalui observasi dan wawancara menggunakan kuesioner.

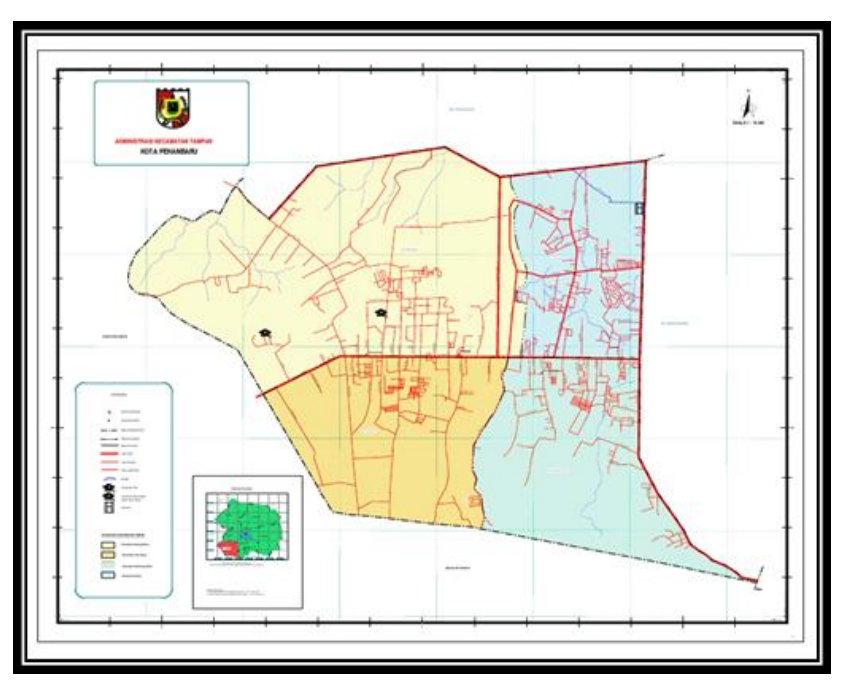

Gambar 1. Lokasi penelitian di Kecamatan Tampan Kota Pekanbaru

Jumlah sampel pada penelitian ini berjumlah 18 responden pekerja bengkel cat. Pemeriksaan sampel urin pekerja menggunakan alat Spektrofotometer UV-Vis (Spektonik 20 Milton Roy, Kuvet Miltan Roy). Analisis yang digunakan yaitu analisis regresi linier berganda. Analisis linier berganda digunakan karena mempunyai lebih dari dua variable independen $\left(\mathrm{X}_{1}, \mathrm{X}_{2}, \ldots, \mathrm{X}_{\mathrm{n}}\right)$ dengan variable dependen $(\mathrm{Y})$ dan a sebagai nilai konstanta, sedangkan $b$ sebagai nilai koefisien dari variabel $\mathrm{X}$.

\section{HASIL}

\section{Kandungan Fenol Dalam Urin Pekerja Bengkel Cat}

Tabel 1. Kandungan Fenol Urin Pekerja Pengecatan Mobil di Kecamatan Tampan Kota Pekanbaru tahun 2017

\begin{tabular}{ccc}
\hline No & $\begin{array}{c}\text { No } \\
\text { Responden }\end{array}$ & $\begin{array}{c}\text { Kandungan fenol urin } \\
(\mathrm{mg} / \mathrm{L})\end{array}$ \\
\hline $\mathbf{1}$ & $\mathbf{A 8}$ & $\mathbf{3 3 , 7 9 6 7}$ \\
$\mathbf{2}$ & $\mathbf{A 1 6}$ & $\mathbf{2 6 , 8 4 4 9}$ \\
$\mathbf{3}$ & $\mathbf{A 6}$ & $\mathbf{2 6 , 3 7 7 0}$ \\
$\mathbf{4}$ & $\mathbf{A 2}$ & $\mathbf{2 1 , 6 3 1 0}$ \\
$\mathbf{5}$ & $\mathbf{A 1 8}$ & $\mathbf{2 0 , 9 6 2 5}$ \\
$\mathbf{6}$ & $\mathbf{A 1 0}$ & $\mathbf{2 0 , 6 9 5 2}$ \\
7 & A7 & 19,4251 \\
8 & A3 & 18,3556 \\
9 & A15 & 18,2219 \\
10 & A9 & 16,0829 \\
11 & A11 & 15,8155 \\
12 & A1 & 15,0134 \\
13 & A13 & 14,6791 \\
14 & A12 & 14,6123 \\
15 & A4 & 13,8101 \\
16 & A14 & 12,6069 \\
17 & A17 & 11,9385 \\
18 & A5 & 4,3181 \\
\hline
\end{tabular}

Sumber: Data Laboratorium Forensik Lingkungan UR (2017)

Dari Tabel 1 diketahui jumlah kandungan fenol urin tertinggi ada pada pekerja A8 sebesar $33,7967 \mathrm{mg} / \mathrm{L}$ dan yang paling terendah kandungan fenol urin adalah A5 sebesar 4,3181 $\mathrm{mg} / \mathrm{L}$. Dari hasil laboratorium diketahui 6 orang pekerja yang mempunyai nilai fenol $>20$ mg/L yaitu pekerja A8 dengan kandungan fenol $33,7967 \mathrm{mg} / \mathrm{L}$, pekerja A16 dengan kandungan fenol 26,8449 mg/ L, pekerja A6 dengan kandungan fenol 26,3770 $\mathrm{mg} / \mathrm{L}$, pekerja A16 dengan kandungan fenol 26,8449 $\mathrm{mg} / \mathrm{L}$, pekerja A2 dengan kandungan fenol 21,6310 mg/ L, pekerja A18 dengan kandungan fenol 20,9625 $\mathrm{mg} / \mathrm{L}$, pekerja A10 dengan kandungan fenol $20,6925 \mathrm{mg} / \mathrm{L}$.

\section{Karakteristik Responden}

\section{a. Usia}

Dari penelitian diketahui usia remaja pekerja (12-25 tahun) sebesar 33,3\%, kategori dewasa (26-45 tahun) $61,1 \%$ dan lansia (46-65 tahun) 5,6\% menurut Depkes RI (2009) (lihat tabel 2).

Tabel 2. Usia Pekerja Pengecatan Mobil di Kecamatan Tampan Kota Pekanbaru tahun 2017

\begin{tabular}{cccc}
\hline & Usia & $\mathrm{n}$ & $\%$ \\
\hline a. & Remaja (12- 25 tahun) & 6 & 33,3 \\
b. & Dewasa (26 - 45 tahun) & 11 & 61,1 \\
c. & Lansia (46 - 65 tahun) & 1 & 5,6 \\
\hline & Jumlah & 18 & 100 \\
\hline
\end{tabular}

Sumber: Analisis Data (2017) 


\section{b. IMT}

Tabel 3. IMT Pekerja Pengecatan Mobil di Kecamatan Tampan Kota Pekanbaru tahun 2017

\begin{tabular}{llcc}
\hline & \multicolumn{1}{c}{ IMT } & $\mathrm{n}$ & $\%$ \\
\hline a. & Kurus $(<17)$ & 2 & 11,1 \\
b. & Normal $(18,5-25)$ & 14 & 77,8 \\
c. & Gemuk $(>25)$ & 2 & 11,1 \\
\hline \multicolumn{1}{c}{ Jumlah } & 18 & 100 \\
\hline
\end{tabular}

Sumber: Analisis Data (2017)

Pada penelitian ini diketahui jumlah pekerja masih dalam normal, dimana jumlah IMT pekerja adalah normal sebanyak $77,8 \%$, kurus dan gemuk masing-masing $11,1 \%$.

\section{c. pendidikan}

Pada penelitian diketahui Tabel 4 pendidikan pekerja pengecatan mobil adalah sebagai berikut:

Tabel 4. Pendidikan Pekerja Pengecatan Mobil di Kecamatan Tampan Kota Pekanbaru tahun 2017

\begin{tabular}{llcc}
\hline \multicolumn{1}{c}{ Pendidikan } & $\mathrm{n}$ & $\%$ \\
\hline a. & Tidak tamat SD/MI & 1 & 5,6 \\
b. & SD/MI & 1 & 5,6 \\
c. & SMP/ MTS & 4 & 22,2 \\
d. & SMA/ SMK/ MA & 11 & 61,1 \\
e. & Diploma/ Sarjana & 1 & 5,6 \\
\hline \multicolumn{2}{r}{ Jumlah } & 18 & 100 \\
\hline
\end{tabular}

Sumber: Analisis Data (2017)

Pekerja terbanyak pada tingkat pendidikan terakhir yaitu tamat SMA/ SMK/ MA sebanyak $61,1 \%$ pekerja, tamat SMP/ MTS sebanyak 22,2\% dan tidak tamat SD/MI, SD/ MI, dan Diploma/ Sarjana masing-masing sebesar $5,6 \%$.

\section{d. Kebiasaan merokok}

Tabel 5. Perilaku Merokok pada Pekerja Pengecatan Mobil di Kecamatan Tampan Kota Pekanbaru tahun 2017.

\begin{tabular}{llcc}
\hline \multicolumn{1}{c}{ Kategori perokok } & $\mathrm{N}$ & $\%$ \\
\hline a. & Perokok ringan (1-4 & 2 & 11,1 \\
& batang/ hari) & 2 & 11,1 \\
b. $\quad \begin{array}{l}\text { Perokok sedang (5-15 } \\
\text { batang/ hari) }\end{array}$ & 14 & 77,8 \\
c. $\begin{array}{l}\text { Perokok berat (>15 } \\
\text { batang/hari) }\end{array}$ & & \\
\hline \multicolumn{1}{c}{ Jumlah } & 18 & 100
\end{tabular}

Sumber: Analisis Data (2017)

Tabel 5 diketahui pekerja yang termasuk kategori perokok berat sebanyak $77,8 \%$ dan yang kategori perokok ringan dan sedang adalah $11,1 \%$.

\section{e. Lama kerja}

Tabel 6. Lama Kerja Pekerja Pengecatan Mobil di Kecamatan Tampan Kota Pekanbaru tahun 2017

\begin{tabular}{cccc}
\hline \multicolumn{2}{c}{ Kategori Lama Kerja } & N & $\%$ \\
\hline a. & $<1$ tahun & - & - \\
b. & $1-3$ tahun & 4 & 22,2 \\
c. $\quad>3$ tahun & 14 & 77,8 \\
\hline & Jumlah & 18 & 100
\end{tabular}

Sumber: Analisis Data (2017)

Tabel 6 tersebut pekerja yang bekerja 1-3 tahun sebesar $22,2 \%$, sedangkan yang bekerja di atas 3 tahun yaitu sebesar 77,8\%.

\section{f. Lama jam kerja}

Tabel 7. Lama Jam kerja pada Pekerja Pengecatan Mobil di Kecamatan Tampan Kota Pekanbaru Tahun 2017

\begin{tabular}{lccc}
\hline Lama jam kerja & $\mathrm{n}$ & $\%$ \\
\hline a. & $<8$ jam/ hari & - & - \\
b. & 8 jam/ hari & 8 & 44,4 \\
c. & $>8$ jam/ hari & 10 & 55,6 \\
\hline & Jumlah & 18 & 100
\end{tabular}

Sumber: Analisis Data (2017)

Diketahui sebanyak $44,4 \%$ pekerja bekerja sesuai dengan jam kerja yaitu 8 jam/ hari. Jumlah jam kerja nomal yaitu 8 jam/ hari dan 5 hari dalam seminggu (KEP/102/MEN/VI/2004). Pekerja yang bekerja $>8 \mathrm{jam} /$ hari selama 6 hari sebanyak 55,6\%.

\section{g. Pemakaian APD}

Tabel 8 Pemakaian APD pada Pekerja Pengecatan Mobil di Kecamatan Tampan Kota Pekanbaru Tahun 2017

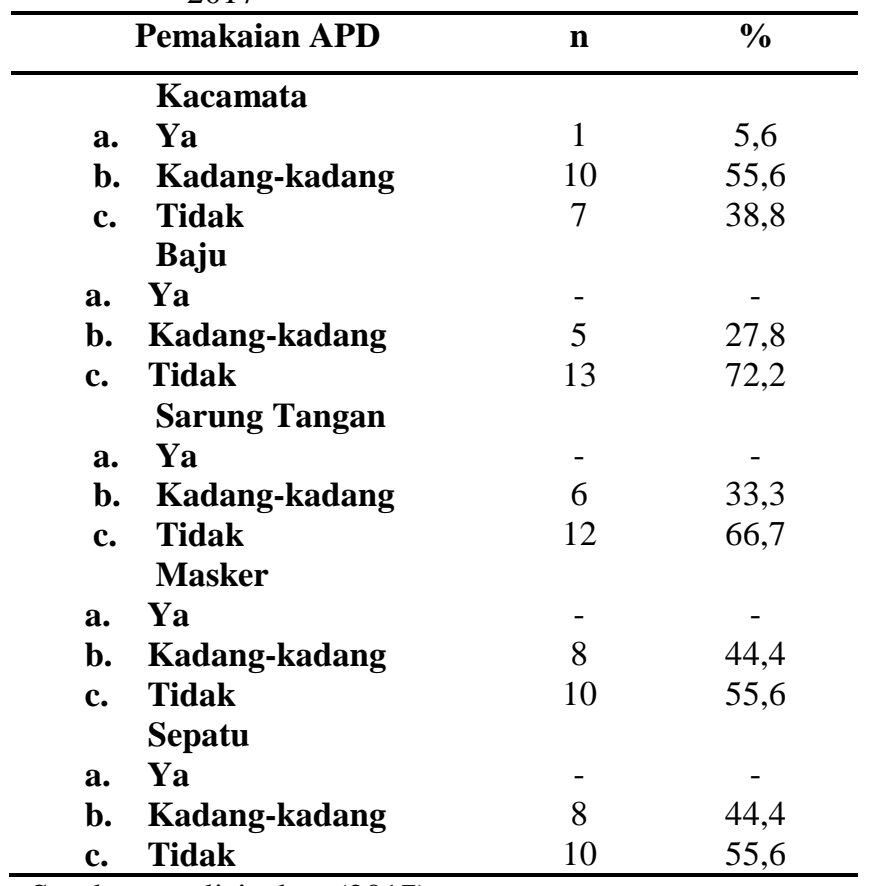

Sumber: analisis data (2017) 
Diketahui pekerja tidak selalu memakai APD dalam bekerja, sebanyak 55,6\% kadangkadang memakai APD kacamata, 27,8\% kadang-kadang memakai APD baju, 33,3\% pekerja yang kadang-kadang memakai APD sarung tangan, 44,4\% yang kadang-kadang memakai APD masker dan sepatu.

\section{Kondisi Lingkungan Bengkel Cat}

Besarnya pertumbuhan penduduk di Kecamatan Tampan membuat banyaknya bengkel cat di lingkungan perumahan. Bengkel cat yang berada di perumahan warga masih bersifat konvensional dengan menggunakan peralatan sederhana. Untuk sirkulasi udara pada bengkel umumnya mempunyai ventilasi yang memadai, dimana bengkel cat mobil mempunyai bangunan semi terbuka dan sederhana.

Pengaruh Karateristik Responden Terhadap Paparan Benzena

Tabel 9. Hasil Pengujian Variabel Pekerja Pengecatan Mobil di Kecamatan Tampan Kota Pekanbaru

\begin{tabular}{|c|c|c|c|c|c|}
\hline & \multicolumn{2}{|c|}{$\begin{array}{c}\text { Unstandardized } \\
\text { Coefficients }\end{array}$} & \multirow{2}{*}{$\mathrm{t}$} & \multirow{2}{*}{$\begin{array}{c}\text { Signif } \\
\text { icant }\end{array}$} & \multirow{2}{*}{ Keterangan } \\
\hline & B & $\begin{array}{c}\text { Std. } \\
\text { Error }\end{array}$ & & & \\
\hline$($ Constant $)$ & $-18,135$ & 14,544 & $-1,247$ & 0,244 & \\
\hline $\mathrm{X}_{1}$ & $-9,090$ & 2,743 & $-3,314$ & 0,009 & Signifikan \\
\hline $\mathbf{X}_{2}$ & 13,100 & 2,598 & 5,042 & 0,001 & Signifikan \\
\hline $\mathrm{X}_{3}$ & 1,479 & 2,131 & 0,694 & 0,505 & Tidak Sig \\
\hline $\mathrm{X}_{4}$ & $-4,258$ & 2,026 & $-2,102$ & 0,065 & Tidak Sig \\
\hline $\mathbf{X}_{5}$ & $-5,557$ & 1,831 & $-3,034$ & 0,014 & Signifikan \\
\hline $\mathbf{X}_{6}$ & 13,224 & 2,782 & 4,753 & $\mathbf{0 , 0 0 1}$ & Signifikan \\
\hline $\mathrm{X}_{7}$ & 2,785 & 1,928 & 1,444 & 0,183 & Tidak Sig \\
\hline $\mathrm{X}_{8}$ & 1,423 & 2,164 & 0,656 & 0,528 & Tidak Sig \\
\hline \multicolumn{3}{|c|}{$\mathbf{R}$ square $\left(\mathbf{R}^{2}\right)$} & $\mathbf{0 , 8 8 5}$ & & \\
\hline \multicolumn{3}{|c|}{ F Hitung } & 8,624 & & \\
\hline \multicolumn{3}{|c|}{ Significant Anova } & 0,002 & & \\
\hline
\end{tabular}

Sumber: Data Analisis 2017

Ket:

X1 Lama Kerja

X2 Lama Jam Kerja

X3 Kebiasaan Merokok

X4 APD Kacamata

X5 APD Masker

X6 APD Sarungtangan

X7 APD Baju

X8 APD Sepatu

\section{PEMBAHASAN}

\section{Kandungan Fenol Dalam Urin Pekerja Bengkel Cat}

Benzena yang masuk dalam tubuh melalui kulit dan terhirup akan mengalami metabolisme yang utama menjadi benzena epoksida. Di dalam hati, benzena epoksida merupakan senyawa yang tidak stabil dan akan segera mengalami perubahan membentuk fenol yang akan dikeluarkan melalui urin. Batas normal fenol urin seseorang adalah $<20 \mathrm{mg} / \mathrm{L}$. Kandungan fenol urin yang melebihi standar harus diwaspadai terhadap kejadian keracunan, karena merupakan gambaran tingkat pemaparan terhadap benzena. Semakin tinggi kandungan fenol dalam urin dapat diasumsikan semakin berat tingkat paparan benzena.

Paparan benzena dalam kandungan tinggi menyebabkan efek narkotik dan iritasi pada mata dan mukosa napas, paparan jangka panjang dengan kandungan rendah dapat berakibat supresi sumsum tulang dan dapat dihubungkan dengan kejadian leukimia atau gangguan hematopoetik lainnya (Maywati, 2012). Menurut Syafar (2015) benzena ditemukan di dalam campuran beberapa pelarut. Benzena adalah senyawa yang mudah menguap, dan terpapar secara luas dalam bentuk uap menyebabkan kerusakan susunan syaraf pusat, saluran pencernaan, dan sumsum tulang yang membentuk sel- sel darah merah. Kontak dalam waktu yang lama dengan kulit menyebabkan kerusakan kulit mirip akibat terbakar, dan beberapa pekerja menjadi lebih sensitif.

Studi epidemiologi yang dilakukan oleh Putra (2003) terhadap para pekerja yang terpapar benzena dalam periode waktu yang lama menunjukkan bertambahnya pekerja yang menderita kanker, terutama kanker darah (leukimia). Partikel cat dalam aktivitas pengecatan terdiri dari berbagai macam bahan kimia berbahaya seperti VOC (volatile organic compound) yang biasanya berupa solvent atau tiner, resin, timbal, kromium, kadmium, kobalt, merkuri, isosianat dan hidrokarbon. Bahan-bahan tersebut bersifat toksik dan merupakan bahan karsinogenik (Wahyuningsih, 2003). 


\section{Karakteristik Responden}

a. Usia

Usia seseorang akan mempengaruhi daya tahan tubuh terhadap paparan zat toksik atau bahan kimia. Usia seseorang dapat berpengaruh terhadap toksisitas karena pada usia tertentu yaitu pada usia lanjut yaitu lebih dari 45 tahun terjadi penurunan faal organ tubuh sehingga mempengaruhi metabolisme dan penurunan kerja otot.

\section{b. IMT}

Sebesar 77,8\% IMT pekerja masih dalam kategori normal, sehingga kemampuan kerja dan daya tahan tubuh berdasarkan status gizi cukup baik. Sebesar $11,1 \%$ pekerja IMT kurus dan gemuk, semakin besar berat badan seseorang maka semakin banyak lemak yang dapat melindungi organ tubuh. Lemak bersifat sangat membantu dalam tubuh untuk menyerap zat kimia.

\section{c. Pendidikan}

Tingkat pendidikan mempengaruhi perilaku dan menghasilkan banyak perubahan, khususnya pengetahuan di bidang kesehatan. Semakin tinggi tingkat pendidikan formal semakin mudah menyerap informasi termasuk juga informasi kesehatan, semakin tinggi pula kesadaran untuk berperilaku hidup sehat. Pendidikan dapat meningkatkan kematangan intelektual seseorang. Kematangan intelektual ini berpengaruh pada wawasan, cara berfikir, baik dalam cara pengambilan keputusan maupun dalam pembuatan kebijakan, jadi semakin tinggi pendidikan formal akan semakin baik pengetahuan tentang kesehatan (Budiono, 2003).

\section{d. Kebiasaan Merokok}

Dari hasil kuesioner sebanyak 14 pekerja merokok lebih dari 15 batang/ hari dan termasuk perokok berat. Perilaku kebiasaan merokok pekerja saat bekerja dan sesudah bekerja tidak dapat dihentikan. Merokok merupakan faktor penggangu yang potensial dalam monitoring biologis terhadap paparan benzena. Orang yang merokok satu pak per hari, diperkirakan mendapat paparan benzena sekitar $1 \mathrm{mg}$ (3-4\%) benzena (Sipayung, 2015)

\section{e. Lama kerja}

Semakin lama seseorang bekerja maka semakin besar tingkat risiko paparan benzena ke dalam tubuh. Lama kerja merupakan lamanya seseorang terpapar oleh bahan kimia secara terus menerus. Benzena yang masuk ke dalam tubuh akan beredar mengikuti aliran darah dan terdeposit pada organ target yaitu sumsum tulang, otak, jaringan lemak. Akumulasi benzena dalam lemak berlangsung lambat, namun ada potensi penyerapan yang tinggi pada jaringan karena sifatnya yang larut dalam lemak (Maywati dan Siti, 2011).

\section{f. Lama jam kerja}

Lama jam kerja yang berbeda, hal ini dikarenakan hanya sendiri pekerja mengerjakan pengecatan mobil, jadi tidak mempunyai aturan waktu sampai jam berapa bekerja. Sebanyak 15 pekerja yang bekerja 6 hari kerja selama seminggu, hal ini dikarenakan sistem kerja yang digunakan adalah sistem borongan karena banyaknya mobil yang dicat.

Jumlah jam kerja per minggu pada aktivitas pekerja terpapar benzena dapat digunakan untuk memperkirakan kumulatif paparan yang diterima oleh seorang pekerja. Lama paparan pada pekerja ini berkaitan langsung dengan banyaknya benzena yang terpapar pada responden selama berada di bengkel. Walaupun benzena yang dihirup setiap hari tidak diketahui berapa banyaknya, namun dalam waktu yang lama akan mempengaruhi jumlah benzena itu sendiri.

\section{g. Pemakaian APD}

Berdasarkan hasil wawancara dengan pekerja dan pemilik bengkel diketahui bahwa faktor yang menyebabkan pekerja jarang memakai APD selama bekerja adalah karena pekerja merasa tidak nyaman dan merasa terganggu dalam melakukan pekerjaannya sehingga tidak jarang para pekerja banyak yang tidak memakai APD dalam bekerja. Banyaknya pekerja tidak memakai APD pada saat bekerja hal ini ketika ditanyakan kepada pekerja karena merasa tidak nyaman, terganggu dan kepanasan serta tidak tersedianya APD yang mendukung dalam melakukan pekerjaan.

Pemilihan APD yang handal secara cermat adalah merupakan persyaratan mutlak yang sangat mendasar. Pemakaian APD yang 
tidak tepat dapat mencelakaan tenaga kerja yang memakainya karena responden tidak terlindung dari bahaya potensial yang ada di tempat responden terpapar (Tarwaka, 2008).

\section{Kondisi Lingkungan Bengkel Cat}

Kualitas dan perubahan udara masuk bergantung dari suhu, kelembaban, ventilasi. Suhu udara yang baik tidak melebihi $30^{\circ} \mathrm{C}$ (Syafar, 2015) dan kelembaban tidak melebihi 78\%. Pembuangan limbah di bengkel home industry tidak mempunyai, hanya menumpuk sisa kaleng cat di sudut ruangan bengkel cat, sehingga sisa-sisa cat dapat mencemari tanah dan air tanah di sekitar perumahan, dimana benzena sulit di degradasi oleh tanah. Luas ruangan bengkel rata-rata hanya $25 \mathrm{~m}-30 \mathrm{~m}$, setiap kebutuhan aktivitas yang dilakukan bergantung dari luas ruangan tersebut. Semakin padat kendaraan yang akan di cat maka akan mengakibat ruangan tersebut menjadi pengap dan menjadi tidak nyaman untuk ditempati.

\section{Pengaruh Karateristik Responden Terhadap Paparan Benzena}

Tabel 8 di atas menunjukkan adapun persamaan regresi linier berganda yang signifikansi berpengaruh terhadap karakteristik pekerja pengecatan mobil dengan kandungan fenol dalam urin, sebagai berikut:

$$
\begin{aligned}
Y= & a+b_{1} X_{1}+b_{2} X_{2}+b_{5} X_{5}+b_{6} X_{6} \\
& =-18,135-9,090 X_{1}+13,100 X_{2}-5,557 \\
& X_{5}+13,224 X_{6}
\end{aligned}
$$

Variabel $\mathrm{Y}$ adalah dependen yaitu jumlah kandungan fenol urin, nilai a adalah nilai constant, dan $\mathrm{b}$ adalah coefficients Berdasarkan persamaan regresi tersebut diketahui bahwa lama kerja, lama jam kerja, pemakaian APD sarung tangan dan masker ada pengaruh terhadap kandungan fenol urin pekerja cat mobil di Kecamatan Tampan Kota Pekanbaru.

Persamaan dari regresi linear menunjukkan bahwa setiap penambahan satu hari/ jam variabel lama jam kerja, maka akan menaikkan variabel kandungan fenol dalam urin sebesar 13,100. Begitu juga untuk variabel APD sarung tangan, bahwa setiap tidak memakai APD sarung tangan, maka akan menaikkan variabel kandungan fenol dalam urin sebesar 13,224. Variabel lama kerja menunjukkan bahwa setiap pengurangan satu tahun, maka akan mengurangi kandungan fenol dalam urin sebesar 9,090. Begitu juga untuk variabel APD masker, setiap pekerja memakai APD Sarung tangan, maka akan mengurangi kandungan fenol dalam urin sebesar 5,557.

Nilai koefisien determinasi ( $R$ Square) dapat dipakai untuk memprediksi seberapa besar kontribusi pengaruh variabel bebas $(\mathrm{X})$ terhadap variabel terikat $(\mathrm{Y})$ dengan syarat hasil uji $\mathrm{F}$ dalam analisis regresi bernilai signifikansi. Nilai secara keseluruhan didapatkan $\mathrm{R}^{2}$ sebesar $88,5 \%$ artinya pengaruh variabel lama kerja, lama jam kerja, pemakaian APD sarung tangan dan masker terhadap kandungan fenol dalam urin sangat besar. Sedangkan sisanya $11,5 \%$ dipengaruhi oleh variabel lain di luar model regresi ini. Menurut peneliti variabel lain di luar model ini antara lain riwayat penyakit, kebiasaan berolahraga, status gizi, konsumsi obat-obatan, hal ini sependapat dengan Kusuma et al, (2006), juga dengan Pudyoko (2010) yang menyatakan fenol dalam urin dipengaruhi oleh riwayat penyakit, buah-buahan, sayuran, penyakit yang diderita dan obat-obatan.

Nilai significant secara keseluruhan pada hasil yaitu $0,002<0,05$ yang artinya secara keseluruhan variabel lama kerja, lama jam kerja, pemakaian APD masker dan sarung tangan terhadap kandungan fenol urin tidak terdapat perbedaan yang nyata antara variabel bebas dengan variabel terikat.

\section{KESIMPULAN}

Kandungan fenol dalam urin yang melebihi standar harus diwaspadai terhadap kejadian keracunan, karena merupakan gambaran tingkat pemaparan terhadap benzena. Semakin tinggi kandungan fenol dalam urin dapat diasumsikan semakin berat tingkat paparan benzena. Paparan benzena dalam kandungan tinggi menyebabkan efek narkotik dan iritasi pada mata dan mukosa napas, paparan jangka panjang dengan kandungan rendah dapat berakibat supresi sumsum tulang dan dapat dihubungkan dengan kejadian leukimia atau gangguan hematopoetik lainnya. 


\section{SARAN}

Kondisi lingkungan disekitar bengkel memprihatinkan, serta tidak mempunyai pembuangan limbah dan dapat mencemari air, tanah dan udara di sekitar perumahan tersebut. Hendaknya pekerja menggunakan APD yang sesuai dengan pekerjaannya, untuk meminimalkan risiko paparan dari benzena yang dapat masuk ke dalam tubuh.

\section{UCAPAN TERIMA KASIH}

Penulis mengucapkan terimakasih kepada pihak-pihak yang telah membantu baik dalam bentuk materiil dan moril dalam penelitian ini, sehingga dapat terlaksana dengan baik penelitian ini.

\section{DAFTAR PUSTAKA}

Agency for Toxic Substances and Disease Registry (ATSDR), 2005.

Toxicological profiles for benzene (Draft for Public Comment).U.S. Department of Health and Human Services, Public Health Service, Atlanta, Georgia, U.S.A.

Profile for Benzene. U.S. Department of Health and Human Service.

Budiono, S. 2003. Bunga Rampai Hiperkes dan Keselamatan Kerja. Semarang: Penerbit Universitas Diponegoro.

Budiono, I. 2007. Faktor Risiko Gangguan Fungsi Paru Pada Pekerja Pengecatan Mobil (Studi Pada Bengkel Pengecatan Mobil Di Kota Semarang) Program Studi Magister Epidemiologi Unversitas Diponegoro. Semarang

Departemen Kesehatan Republik Indonesia. 2009. Profil Kesehatan Indonesia. Jakarta.

Departemen Tenaga Kerja Republik Indonesia. 2011. Surat Edaran Menteri Tenaga Kerja No. Per 13/MEN/X/2011 tentang Nilai Ambang Batas Faktor Kimia di Udara Lingkungan Kerja. Jakarta.

Keputusan Menteri Tenaga Kerja dan Transmigrasi Republik Indonesia. Nomor KEP. 102/ MEN/ VI/ 2004.
Tentang Waktu Kerja Lembur dan Upah Kerja Lembur.

Kusuma, A.A, Onny, S dan Tri, J. 2006. Analisis Pemajanan Benzene Terhadap Kandungan Fenol Dalam Urin Dan Status Anemi Pada Pekerja Sector Industri Pengolahan Petroleum. Jurnal Kesehatan Lingkungan 5 (2) : 65-68

Maywati, S. 2012. Kajian Faktor Individu terhadap Fenol Urin Pekerja Bagian Pengeleman Sandal. Jurusan Ilmu Kesehatan Masyarakat, Fakultas Ilmu Kesehatan, Universitas Siliwangi Tasikmalaya, Indonesia. Jurnal KESMAS 7 (2) (2012): 142-148

Maywati, S dan Siti, N. 2011. Hubungan Faktor Pemajanan (Masa Kerja Dan Ventilasi) Dengan Kandungan Fenol Urin Pekerja Bagian Pengeleman Pada Industri Sandal Kota Tasikmalaya 2011. Jurnal KESMAS 4 (2): 70-75

Sipayung, L. P. 2015. Korelasi Paparan Benzena melalui Pemeriksaan kadar transmuconic acid (ttMA) dalam urin dengan Gambaran Blood Count (CBC) pada urin Karyawan di stasiun pengisian Bahan Bakar Umum (SPBU) $X$ dan Y PT. Pertamina Medan. Tesis. Magister Ilmu Biomedik. Fakultas Kedokteran Universitas Sumatera Utara. Medan

Sugiharto, E. T.P. 2009. Hubungan antara Perilaku Penggunaan Insektisida Dalam Pengendalian Hama Ulat Bawang (Spodoptera Exigua Hbn) Dengan Tingkat Keracunan Petani Penyemprot Bawang Merah Di Desa Bangsal Rejo, Kec. Wedari Jaksa, Kab. Pati. Jurnal Kesmas, 4 (2): 132-139.

Syafar, M. dan Abdul, W. W. 2015. Analysis Of Benzene Concentration Effect Of Workplace To The Phenol Concentration In Urine Of Painting Workshop Labors In Makassar Indonesia. International Journal of Science: Basic And Applied Research 21 (2) : 439-445

Tarwaka. 2008. Keselamatan dan Kesehatan Kerja Manajemen dan Implementasi K3 di tempat kerja. Surakarta: Harapan Press.

Rahim, A., Ni Made, S dan Wiwik, S. R. 
2015. Analisis Fenol dalam Urin Pekerja Salah Satu Stasiun Pengisian Bahan Bakar Umum di Kota Denpasar. Jurnal Kimia 9 (1), Januari 2015: 105 108.

Pudyoko, S. 2010. Hubungan Pajanan Benzene dengan kandungan Phenol dalam Urin dan Gangguan Sistem Hematopoietik pada Pekerja Instalasi BBM. Tesis. Semarang: Magister Kesehatan Lingkungan Universitas Diponegoro Semarang
Vitalli, M, Ensabella, F, Stella, D dan Guidotti, M. 2005. Exposure to Organic Solvents among Handicraft Car Painters: A Pilot Study in Italy. Industrial Health 2006: 44: 310-317

WHO. 1996. Biological Monitoring of Selected Solvent. Geneva. 